\title{
CLINICAL AND RADIOGRAPHIC ASSESSMENT OF IMPLANT OVERDENTURES RETAINED BY DIFFERENT ATTACHMENT SYSTEMS
}

\author{
Nada El Khourazaty* and Nagla Nassouhy*
}

\begin{abstract}
Objectives: To compare two different attachments for implant overdentures; ball attachment with nylon matrix and OLS attachment with PEEK matrix regarding bone height changes and implant stability.

Materials and Methods: Ten completely edentulous patients were selected and two implants were inserted in the interforaminal region for each patient. After 3 months of installation, the patients were divided into two equal groups; group I receiving overdentures retained with ball attachments and group II receiving overdentures retained with OLS attachments. Implant stability was measured using Periotest and digital radiography was used for bone height assessment at time of prosthesis insertion and at 6,12 and 24 months later.
\end{abstract}

Results: No significant difference was found regarding Periotest values and bone loss at all follow-up appointments for both groups. There was also no difference between the two groups regarding Periotest values and bone loss at all follow-up appointments.

Conclusions: Comparable performance of the two attachments was observed regarding both Periotest values and bone loss at 6,12 and 24 months of function.

\section{INTRODUCTION}

Prosthetic rehabilitation of totally edentulous patients today is a common procedure that clinicians approach in their daily practice. The use of dental implants for replacing missing teeth proved to be a safe technique and the implant-prosthetic materials available give the possibility of having long-term clinical success ${ }^{1,2}$.

Many studies have recommended the mandibular implant overdenture as a reliable treatment modality for edentulous patients and, in particular, those who have persistent problems using conventional

\footnotetext{
* Lecturer of Removable Prosthodontics, Cairo University
} 
mandibular prosthesis. Placing interforaminal implants with attachments improve the retention and stability of dentures and achieve greater support by transmitting axial loads to the bone. Additionally, bending moments on implants caused by vertical forces applied to the edentulous region can be reduced by these attachments because of their stress breaking action ${ }^{3-5}$.

Several types of attachments have evolved to connect the denture to implants such as bars, magnets, stud attachments, as well as rigid and resilient telescopic copings. Yet, the necessity for simplifying the selection and usage of attachments for overdenture fixation cannot be overlooked ${ }^{6,7}$. Stud attachments are one of the most commonly used attachments with overdentures due to their ease of handling, cost effectiveness, less technique sensitivity, better stress distribution, and acceptable retention ${ }^{7,8}$.

Ball attachments remain one of the most popular stud attachments and are used extensively with implant overdentures ${ }^{9-11}$. Their design allows a universal hinge movement in all directions; however, the actual movement of the overdenture depends on the arrangement and number of the implant attachments ${ }^{12}$. Ball attachments also facilitate hygiene measures, are simple to use and easy to maintain, with a success rate of almost $100 \%{ }^{7,13}$. On the other hand, wear remains the greatest disadvantage of ball attachments, as some studies have reported that it is the highest among other types of attachments ${ }^{7,14,15}$.

Poly Ether Ether Ketone (PEEK) material was recently introduced as an ideal additive to prosthetic dentistry and implantology due to its good mechanical and physical properties. PEEK has shown flexibility with high mechanical resistance to wear as well as high tensile, fatigue and flexural strength. PEEK is used to produce high-quality plastic parts that are thermo-stable and both electrically and thermally insulating. It also attains low specific mass, elasticity similar to that of bone, and a very low material fatigue ${ }^{16,17}$. It has recently been used as a retentive matrix for bar and stud attachments ${ }^{17,18}$, but long-term research on its clinical performance and effect on peri-implant structures is still limited.

The longevity of any implant prosthesis depends on successful osseointegration and implant stability..$^{19}$ Implant stability assessment is one of the less invasive techniques that are indicative of the success of osseointegration ${ }^{20,49}$. One technique for measuring implant stability is the damping capacity assessment using the Periotest. Periotest values (PTV) range from -8 to +50 , with decreasing stability as the PTV increases. Values above 10 PTV units are indicative of failed osseointegration ${ }^{21}$. Periapical radiography has also been used extensively for the follow-up of dental implants and is considered one of the tools for assessing implant success ${ }^{22-25}$.

This study was conducted to investigate the effect of two attachments with different designs and retentive matrix materials; namely ball attachment with nylon cap and OLS attachment with PEEK cap, on implant stability as well as the marginal bone height surrounding the implants after 6,12 and 24 months of function.

\section{MATERIALS AND METHODS}

\section{Patient Selection}

Ten completely edentulous patients were selected from the outpatient clinic of the Prosthodontics Department; Faculty of Oral and Dental Medicine, Cairo University. The patients' ages ranged from 45-60 years old and were systemically free from any disease that may interfere with dental implant placement and/or osseointegration. Patients also had adequate bone height and width for implant placement, as well as sufficient inter-arch space for overdenture construction with normal maxillo-mandibular relation. Only cooperative patients capable of following instructions and those with proper neuromuscular coordination were included in the study. 
Thorough patient history, clinical examination and radiographic assessment were carefully done for verification of the selection criteria. The patients were familiarized with the nature of the study and requested to sign consent forms before beginning the study.

\section{Construction of Complete Dentures}

Study casts were produced from primary alginate impressions for the upper and lower arches of each patient. Acrylic resin special trays were constructed on the diagnostic casts and used in recording the final impressions using zinc oxide and eugenol impression material. Master casts were obtained and occlusion blocks were constructed for jaw relation registration, followed by mounting of the master casts on the articulator. Setting-up of cross linked acrylic resin teeth was done following the lingualized occlusion concept. Try-in was performed, after which the dentures were processed following conventional techniques using high impact acrylic resin.

\section{Implant Placement}

At the delivery appointment, final occlusal adjustments and refinements were done and the denture was delivered to the patients 6 weeks before the surgical appointment to achieve sufficient patient adaptation. The finished lower denture was duplicated for each patient and processed in clear acrylic resin in order to construct a surgical guide template to facilitate implant placement during surgery.

Two $3.7 \mathrm{~mm}$ in diameter, $10 \mathrm{~mm}$ in length implants* were placed by the aid of the surgical guide in the inter-foraminal area using sequential drilling after flap reflection. The direction of drilling was kept perpendicular to the bone and midway buccolingually, keeping in consideration the parallelism between the two implants. Suturing was done after placement of the cover screws. The dentures were relined with a soft liner to avoid any pressure on the implants during the three months period of the osseointegration.

\section{Overdenture Pick-up}

After 3 months, second stage surgery was performed and the cover screws were removed and replaced with a stud attachment randomly dividing the patients into two equal groups: Group I: receiving mandibular overdentures retained by ball attachments** and nylon matrices, and Group II: receiving mandibular overdentures retained by OLS $^{* * *}$ attachment with PEEK retentive caps (fig 1).

The caps and housings were secured firmly over the ball attachments in group I. Holes corresponding to the housings were drilled in the fitting surface of the denture to allow seating of the denture without any interference with the housings, as proved by absence of rocking, pressure indicating paste and proper occlusion .Cold curing resin was placed in the relieved areas of the denture and the denture was seated in the patient mouth. The resin was left to polymerize while the patient was closing in centric jaw relation with gentle pressure .The overdenture was removed, trimmed and polished with the housings picked up in its fitting surface. The dentures were delivered and oral hygiene instructions were given to the patients. The same procedure was repeated for the pick-up of the OLS attachment in group II (fig 2).

\section{Measurements and Follow-up}

Implant stability and bone height measurements for each implant and attachment were done for the two groups at the time of the delivery of the overdenture and at 6,12 and 24 months after overdenture delivery.

\footnotetext{
* Screw Plant Implants, ImplantDirect, Malibu Hills, USA

** ImplantDirect, Malibu Hills, USA

*** Osteoseal dental implants, California, USA
} 


\section{Implant Stability Measurement}

Implant stability was assessed using a Periotest*. The Periotest was used according to the manufacturer's instructions and held perpendicular to the attachments (fig 3). Periotest values (PTV) were obtained for the buccal, lingual, mesial and distal surfaces of each implant. Three measurements were made for each surface and the mean was obtained for statistical analysis.

\section{Bone height Measurement}

Digital radiography was used to measure bone height changes mesial and distal to the implants using the long cone paralleling technique. A radiographic stent was used for each patient for repeatable imaging sensor position and standardization purposes. Measurements were

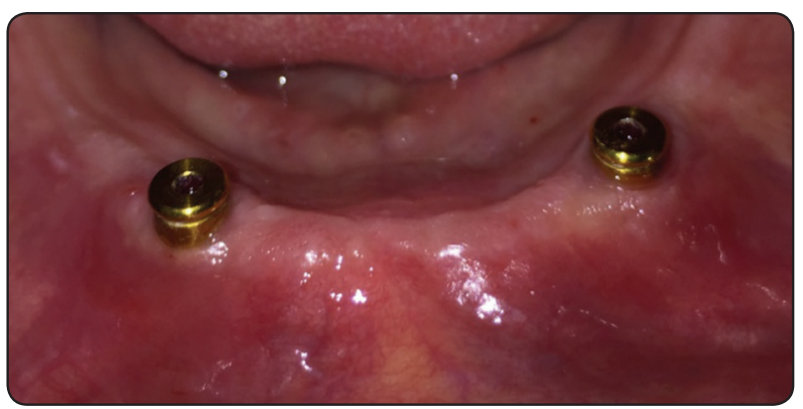

Fig (1) The OLS attachment screwed to the implants

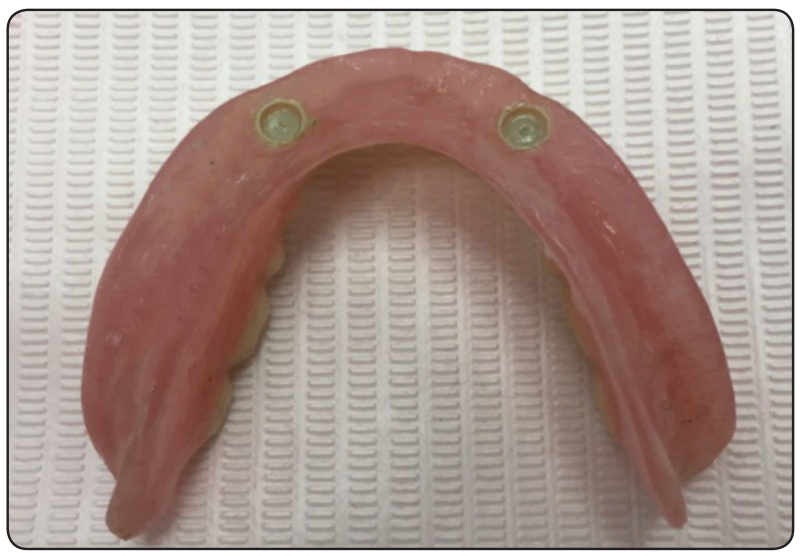

Fig (2) the fitting surface of the denture showing PEEK retentive matrices after pick-up

* Siemens AG, Bensheim, Germany

** DIGORA ${ }^{\circledR}$ for Windows. Soredex, Finland done using the Digora Software ${ }^{* *}$ in the following manner; a horizontal line was extended tangential to the apex of the implant, then two vertical lines were extended perpendicular to the horizontal line to the highest point of the alveolar crest on the mesial and distal sides of each implant (fig 4).

\section{Statistical Analysis}

Mean values were obtained for each implant for Periotest values and bone height measurements. The mean and standard deviation values were calculated for each group in each test. Data were explored for normality using Kolmogorov-Smirnov and ShapiroWilk tests. Data showed normal distribution (Parametric). Independent sample t-test was used to compare between two groups in non-related samples. Repeated measure was used to compare

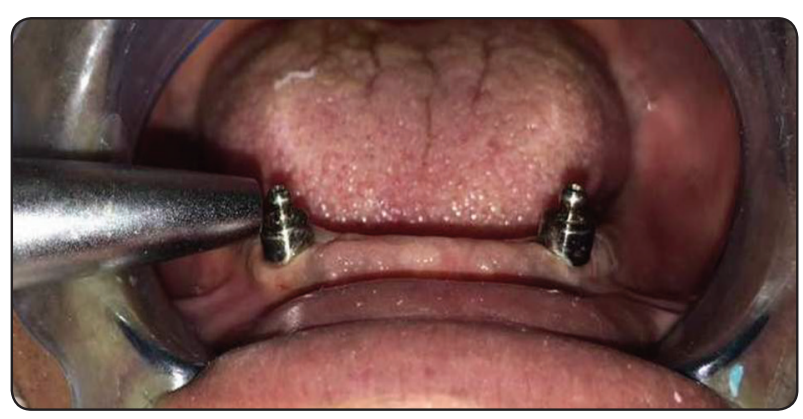

Fig (3) Periotest measurement for the ball attachment

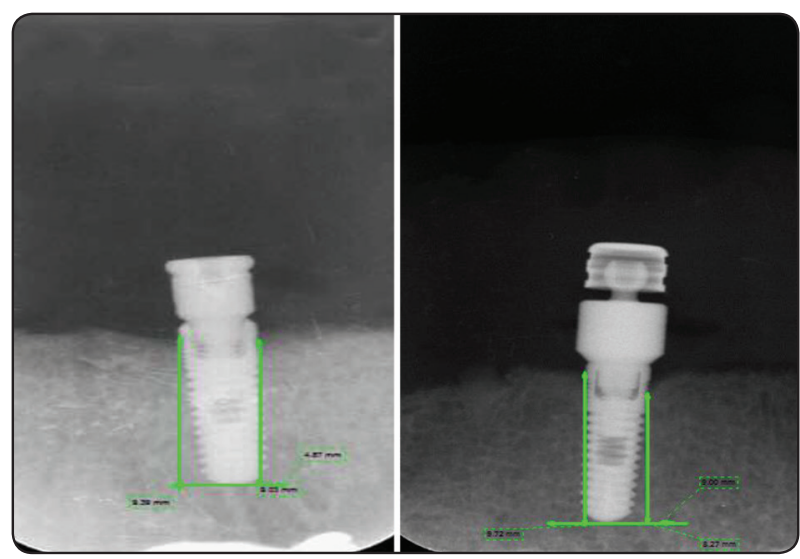

Fig (4) marginal bone height measurements using Digora Software for OLS attachment (left) and ball attachment (right) 
between more than two groups in related samples. Paired sample t-test was used to compare between two groups in related samples. The significance level was set at $\mathrm{P} \leq 0.05$. Statistical analysis was performed with IBM ${ }^{\circledR}$ SPSS ${ }^{\circledR}$ Statistics Version 20 for Windows.

\section{RESULTS}

\section{Implant Stability}

There was a decrease in the mean values of PTV for both groups-denoting an increase in implant stability at 6, 12 and 24 months in both groups. These changes were, however, statistically not significant at all follow up appointments in the two groups. In group I, the lowest mean value of PTV (highest stability) was $-3.98 \pm 0.50$ found at 24 months, while the highest mean value of PTV (lowest stability) was $-3.53 \pm 0.47$ found at the time of prosthesis insertion. As for group II, the lowest mean value of PTV was $-3.60 \pm 0.89$ found at 24 months, while the highest mean value of PTV was $-2.92 \pm 0.44$ found at the time of prosthesis insertion.

On comparing the two groups, no significant difference was found in PTV at the time of prosthesis insertion and at 6,12 and 24 months later. The lowest mean value of PTV was $-3.98 \pm 0.5$ found in group I at 24 months followed by $-3.6 \pm 0.89$ in group II while the highest mean value of PTV was $-2.86 \pm 0.5$ found in group II followed by $-3.53 \pm 0.47$ occurring at the time of prosthesis insertion (table 1, fig 5).

\section{Bone height}

The results of this study showed a decrease in bone height measurement denoting bone loss at 6 , 12 and 24 months after prosthesis insertion in both groups. However, this reduction in bone height was statistically not significant at all follow up appointments. In group I, the highest mean value of bone height was $9.06 \pm 0.21$ found at time of insertion while the lowest mean value of bone height was $8.13 \pm 0.48$ found at 24 months. The amount of bone loss was $0.38 \pm 0.45 \mathrm{~mm}, 0.82 \pm 0.32 \mathrm{~mm}$ and $0.93 \pm 0.42 \mathrm{~mm}$ at 6,12 and 24 months respectively. In group II, the amount of bone loss was $0.37 \pm 0.38$, $0.87 \pm 0.42 \mathrm{~mm}$ and $0.96 \pm 0.37 \mathrm{~mm}$ at 6,12 and 24 months respectively (table 2, 3 fig 6).

TABLE (1) The mean, standard deviation (SD) values of PTV in both groups

\begin{tabular}{|c|c|c|c|c|c|}
\hline \multirow{2}{*}{ Variables } & \multicolumn{4}{|c|}{ PTV } & \multirow{2}{*}{ G-value } \\
\cline { 2 - 5 } & \multicolumn{2}{|c|}{ Group I } & \multicolumn{2}{|c|}{ Group II } & \\
\cline { 2 - 5 } & Mean & SD & Mean & SD & \\
\hline $\begin{array}{c}\text { At time of } \\
\text { insertion }\end{array}$ & $-3.53^{\text {aA }}$ & 0.47 & $-2.86^{\text {aA }}$ & 0.50 & $\mathbf{0 . 0 9 9 n s}$ \\
\hline $\begin{array}{c}\text { After 6 } \\
\text { months }\end{array}$ & $-3.67^{\text {aA }}$ & 0.41 & $-2.92^{\text {aA }}$ & 0.44 & $\mathbf{0 . 0 5 0 n s}$ \\
\hline $\begin{array}{c}\text { After 12 } \\
\text { months }\end{array}$ & $-3.79^{\text {aA }}$ & 0.53 & $-3.03^{\text {aA }}$ & 0.85 & $\mathbf{0 . 1 7 9 n s}$ \\
\hline $\begin{array}{c}\text { After 24 } \\
\text { months }\end{array}$ & $-3.98^{\text {aA }}$ & 0.50 & $-3.60^{\text {aA }}$ & 0.89 & $\mathbf{0 . 4 8 1 n s}$ \\
\hline \begin{tabular}{c} 
p-value \\
\hline
\end{tabular} & $\mathbf{0 . 2 5 1 n s}$ & \multicolumn{2}{|c|}{$\mathbf{0 . 1 5 6 n s}$} & \\
\hline
\end{tabular}

Superscripts with different small letters indicate statistically significance difference within the same column. Superscripts with different capital letters indicate statistically significance difference within the same row.

*; significant ( $p \leq 0.05) \quad n s ;$ non-significant ( $p>0.05)$.

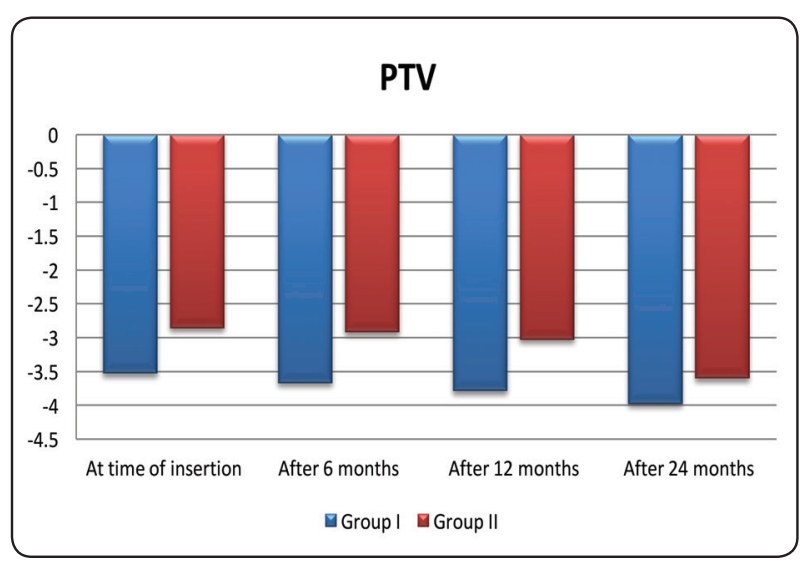

Fig (5) Bar graph showing PTV values in both groups at all follow-up appointments 
On comparing the two groups, the difference in bone height changes was not statistically significant at 6,12 and 24 months after insertion. At the end of the follow-up period of 24 months, Group I had lost $0.93 \mathrm{~mm} \pm 0.42$ of marginal bone $(10.31 \%)$ while group II had lost $0.96 \mathrm{~mm} \pm 0.37$ (10.38\%) (Table 3 , fig 7).

TABLE (2) The mean, standard deviation (SD) values of bone height in both groups

\begin{tabular}{|c|c|c|c|c|c|}
\hline \multirow{2}{*}{ Variables } & \multicolumn{5}{|c|}{ Gone height } \\
\cline { 2 - 6 } & Mean & SD & Mean & SD & \\
\cline { 2 - 6 } & Group I & \multicolumn{2}{c|}{ Group II } \\
\hline $\begin{array}{c}\text { At time of } \\
\text { insertion }\end{array}$ & $9.06 \mathrm{aA}$ & 0.21 & $9.26 \mathrm{aA}$ & 0.23 & $0.323 \mathrm{~ns}$ \\
\hline $\begin{array}{c}\text { After 6 } \\
\text { months }\end{array}$ & $8.68 \mathrm{aA}$ & 0.55 & $8.90 \mathrm{aA}$ & 0.36 & $0.607 \mathrm{~ns}$ \\
\hline $\begin{array}{c}\text { After 12 } \\
\text { months }\end{array}$ & $8.24 \mathrm{aA}$ & 0.40 & $8.39 \mathrm{aA}$ & 0.53 & $0.711 \mathrm{~ns}$ \\
\hline $\begin{array}{c}\text { After 24 } \\
\text { months }\end{array}$ & $8.13 \mathrm{aA}$ & 0.48 & $8.30 \mathrm{aA}$ & 0.48 & $0.674 \mathrm{~ns}$ \\
\hline p-value & \multicolumn{2}{|c|}{$0.059 \mathrm{~ns}$} & $0.051 \mathrm{~ns}$ & \\
\hline
\end{tabular}

Superscripts with different small letters indicate statistically significance difference within the same column. Superscripts with different capital letters indicate statistically significance difference within the same row.

*; significant ( $p \leq 0.05) n s ;$ non-significant ( $p>0.05)$

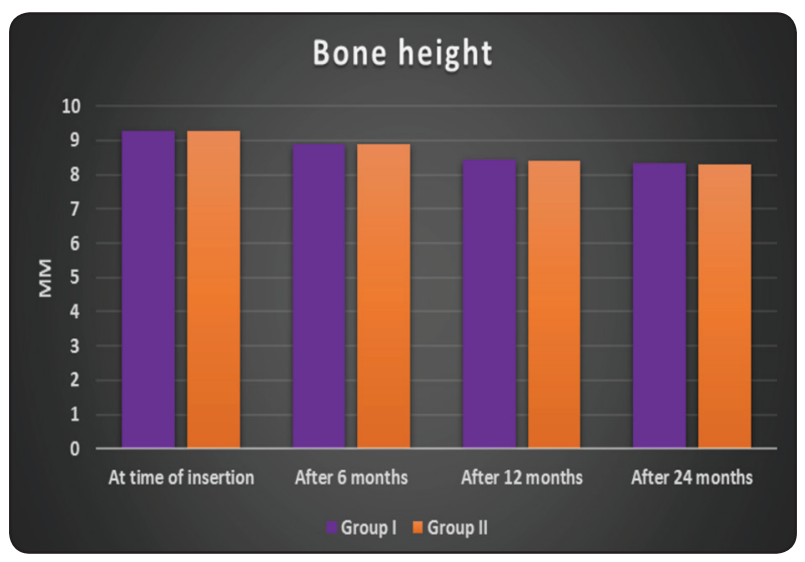

Fig. (6) Bar chart showing bone height measurements in the two groups
TABLE (3) The mean, standard deviation (SD) values of bone loss in both groups

\begin{tabular}{|c|c|c|c|c|c|c|c|}
\hline \multirow{2}{*}{ Variables } & \multicolumn{5}{|c|}{ Bone loss } & \multirow{2}{*}{ p-value } \\
\cline { 2 - 7 } & \multicolumn{3}{|c|}{ Group I } & \multicolumn{3}{|c|}{ Group II } & \\
\cline { 2 - 7 } & Mean & SD & $\%$ & Mean & SD & $\%$ & \\
\hline $\begin{array}{c}\text { After 6 } \\
\text { months }\end{array}$ & 0.38 & 0.45 & $4.18 \%^{\mathrm{a}}$ & 0.37 & 0.38 & $3.94 \%^{\mathrm{a}}$ & \multirow{2}{*}{} \\
\hline $\begin{array}{c}\text { After 12 } \\
\text { months }\end{array}$ & 0.82 & 0.32 & $9.06 \%^{\mathrm{a}}$ & 0.87 & 0.42 & $9.42 \%^{\mathrm{a}}$ & $\mathbf{0 . 9 2 0 n s}$ \\
\hline $\begin{array}{c}\text { After 24 } \\
\text { months }\end{array}$ & 0.93 & 0.42 & $10.31 \%^{\mathrm{a}}$ & 0.96 & 0.37 & $10.38 \%^{\mathrm{a}}$ & $\mathbf{0 . 9 8 4 n s}$ \\
\hline
\end{tabular}

Superscripts with different capital letters indicate statistically significance difference within the same row.

*; significant ( $p \leq 0.05) \quad n s ;$ non-significant ( $p>0.05)$

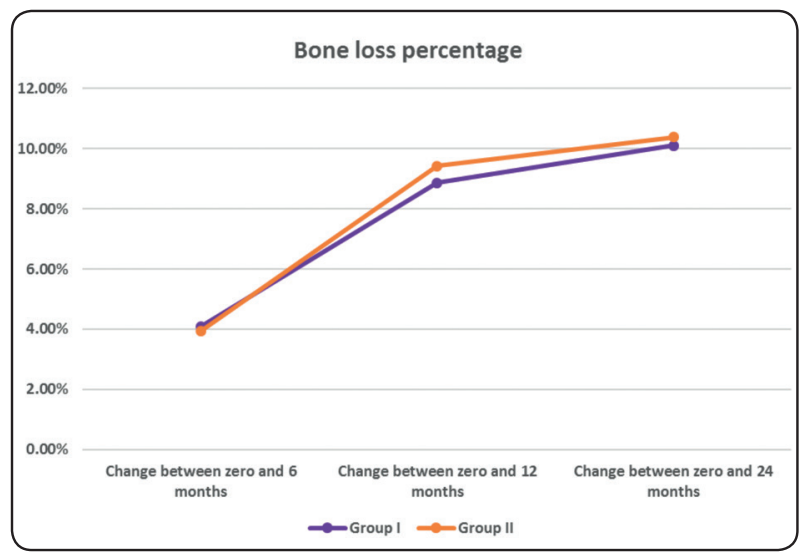

Fig. (7) Line chart representing Bone loss percentage

\section{DISCUSSION}

An attachment should provide optimal force distribution around the implants to allow bone loading within the physiological limits, otherwise, bone resorption as a result of overloading may jeopardize osseointegration ${ }^{26-28}$. Implant stability is considered one of the important indications of successful osseointegration ${ }^{29}$. Periotest is a well-established instrument for assessing implant stability in a reproducible manner that does not require removal of the abutment and therefore does not disturb the soft tissue connection surrounding 
the abutment ${ }^{30,31}$. The results of this study showed an increase in negativity of PTV (denoting higher stability) at 6,12 and 24 months in both groups; however this increase in stability was statistically insignificant at all appointments. The difference between the two groups at the end of the follow-up period was also found to be insignificant.

Marginal bone loss as assessed by digital radiography is one of the indications of the success of osseointegration $^{32}$. The results of this study showed that there was a statistically insignificant bone loss between the time of prosthesis placement and at 6 , 12 and 24 months later in both groups. The total amount of bone loss at the end of the first year was $0.93 \mathrm{~mm}$ and $0.96 \mathrm{~mm}$ in groups I and II respectively. This limited amount of crestal or marginal bone loss is inevitable especially during the first year, and is considered a biological reaction to implant placement and loading as established previously by Albrektsson et al ${ }^{22,33}$. Several studies have reported on marginal bone loss within the range of $1 \mathrm{~mm}$ after one year of function regardless of the type of attachment used $23-25,34,35$.

The difference between the two attachments regarding bone loss at the end of the follow-up period was also statistically insignificant. This comes in accordance with several clinical studies that could find no influence of the type of attachment on marginal bone loss. These findings can be considered controversial, since in vitro studies have confirmed that attachment type and design have an influence on the amount of stresses transferred to the implants and peri-implant bone ${ }^{36,37}$. On the other hand, clinical studies have shown no relation between different types of attachments and the amount of marginal bone loss around the implants ${ }^{38,39}$.

The ball attachment uses a nylon cap as a retentive matrix. Its design allows a universal hinge movement as well as vertical movement owing to the resiliency of the nylon cap. The OLS attachment, on the other hand, has parallel walls and a PEEK retentive matrix with a hole in its center. The results of this study showed that ball attachments had less bone loss percent - although insignificant - after 24 months than OLS attachment. These results suggest that the ball attachment may be providing a more resilient connection to the implants than the OLS attachment, thereby resulting in less marginal bone loss. This, however, does not explain the slightly higher implant stability - although insignificant - with the OLS attachment, suggesting that more research is required on the co-relation between marginal bone loss and implant stability.

The two investigated attachments differ in both design of the patrix and material of the retentive matrix. However, the results of implant stability and bone height assessment of both attachments were comparable. These results are particularly important for the OLS attachment with PEEK matrix where research on its clinical performance is still lacking.

\section{CONCLUSIONS}

The results of this study showed that ball and OLS attachment with PEEK retentive matrix have comparable effects on bone height surrounding the implants. The amount of bone loss after 24 months of function for both attachments was within acceptable levels. Furthermore, Implant stability also increased similarly with the two groups as measured by the Periotest.

\section{REFERENCES}

1. Wang, F. et al. Maxillary Four Implant-retained Overdentures via Locator® Attachment: Intermediateterm Results from a Retrospective Study. Clin. Implant Dent. Relat. Res. 18, (2016).

2. Davis, D. M. Role of implants in the treatment of edentulous patients. Int. J. Prosthodont. 3, 42-50 (1990).

3. Boven, G. C., Raghoebar, G. M., Vissink, A. \& Meijer, H. J. A. Improving masticatory performance, bite force, nutritional state and patient's satisfaction with implant overdentures: A systematic review of the literature. Journal of Oral Rehabilitation 42, 220-233 (2015). 
4. Svetlize, C. a \& Bodereau, E. F. Comparative study of retentive anchor systems for overdentures. Quintessence Int. 35, 443-448 (2004).

5. Scherer, M. D., McGlumphy, E. A., Seghi, R. R. \& Campagni, W. V. Comparison of retention and stability of two implant-retained overdentures based on implant location. J. Prosthet. Dent. 112, (2014).

6. Besimo, C. E. \& Guarneri, A. In vitro retention force changes of prefabricated attachments for overdentures. $J$. Oral Rehabil. 30, 671-678 (2003).

7. Krennmair, G., Weinländer, M., Krainhöfner, M. \& Piehslinger, E. Implant-supported mandibular overdentures retained with ball or telescopic crown attachments: a 3-year prospective study. Int. J. Prosthodont. 19, 164-170 (2005).

8. Passia, N. et al. Single dental implant retained mandibular complete dentures--influence of the loading protocol: study protocol for a randomized controlled trial. Trials $\mathbf{1 5}$, 186 (2014).

9. Naert, I., Alsaadi, G. \& Quirynen, M. Prosthetic aspects and patient satisfaction with two-implant-retained mandibular overdentures: a 10-year randomized clinical study. Int. J. Prosthodont. 17, 401-410 (2004).

10. Naert, I., Alsaadi, G., van Steenberghe, D. \& Quirynen, M. A 10-year randomized clinical trial on the influence of splinted and unsplinted oral implants retaining mandibular overdentures: peri-implant outcome. Int. J. Oral Maxillofac. Implants 19, 695-702 (2004).

11. Klemetti, E., Chehade, A., Takanashi, Y. \& Feine, J. S. Two-implant mandibular overdentures: simple to fabricate and easy to wear. J. Can. Dent. Assoc. 69, 29-33 (2003).

12. Misch CE. Contemporary Implant Dentistry. (Elsevier Mosby, St. Louis, Missouri, 2008).

13. Weinländer, M., Piehslinger, E. \& Krennmair, G. Removable implant-prosthodontic rehabilitation of the edentulous mandible: five-year results of different prosthetic anchorage concepts. Int . J. Oral Maxillofac. Implants 25, 589-97 (2010).

14. Cakarer, S., T. Can, M. Yaltirik, et al. Complications associated with the ball, bar and Locator attachments for implant-supported overdentures. Med Oral Patol Oral Cir Bucal 16, (2011).

15. Fromentin, O., C. Lassauzay, S.A. Nader, et al. Clinical wear of overdenture ball attachments after 1,3 and 8 years. Clin Oral Implant. Res 22, (2011).

16. Najeeb, S., Zafar, M. S., Khurshid, Z. \& Siddiqui, F. Applications of polyetheretherketone (PEEK) in oral implantology and prosthodontics. Journal of Prosthodontic Research 60, 12-19 (2016).

17. Bayer, S. et al. Retention force of plastic clips on implant bars: A randomized controlled trial. Clin. Oral Implants Res. 23, 1377-1384 (2012).

18. Khaled Aziz. Retention Behaviour of Two Different Stud attachments for Overdentures. E.D.J. 62, 3963-3969 (2016).

19. Oh, T.-J., Yoon, J., Misch, C. E. \& Wang, H.-L. The causes of early implant bone loss: myth or science? J. Periodontol. 73, 322-33 (2002).

20. Sennerby, L. \& Meredith, N. Implant stability measurements using resonance frequency analysis: Biological and biomechanical aspects and clinical implications. Periodontol. 2000 47, 51-66 (2008).

21. Olivé, J. \& Aparicio, C. Periotest method as a measure of osseointegrated oral implant stability. The International journal of oral \& maxillofacial implants 5, 390-400 (1990).

22. Albrektsson T, Buser D, S. L. On crestal/marginal bone loss around dental implants. Int J Prosthodont 25, 320-2 (2012).

23. Fernández-Formoso, N., Rilo, B., Mora, M. J., MartínezSilva, I. \& Díaz-Afonso, A. M. Radiographic evaluation of marginal bone maintenance around tissue level implant and bone level implant: A randomised controlled trial. A 1-year follow-up. J. Oral Rehabil. 39, 830-837 (2012).

24. Kadkhodazadeh, M., Heidari, B., Abdi, Z., Mollaverdi, F. \& Amid, R. Radiographic evaluation of marginal bone levels around dental implants with different designs after 1 year. Acta Odontol. Scand. 71, 92-95 (2013).

25. Shin, Y.-K., Han, C.-H., Heo, S.-J., Kim, S. \& Chun, H.J. Radiographic evaluation of marginal bone level around implants with different neck designs after 1 year. Int. $J$. Oral Maxillofac. Implants 21, 789-94 (2005).

26. Chee, W. \& Jivraj, S. Failures in implant dentistry. BDJ 202, 123-129 (2007).

27. Kozlovsky, A. et al. Impact of implant overloading on the peri-implant bone in inflamed and non-inflamed periimplant mucosa. Clin. Oral Implants Res. 18, 601-610 (2007).

28. Chambrone, L., Chambrone, L. A. \& Lima, L. A. Effects of Occlusal Overload on Peri-Implant Tissue Health: A Systematic Review of Animal-Model Studies. $J$. Periodontol. 81, 1367-1378 (2010).

29. Oh, J. S. \& Kim, S. G. Clinical study of the relationship between implant stability measurements using Periotest 
and Osstell mentor and bone quality assessment. Oral Surg. Oral Med. Oral Pathol. Oral Radiol. 113, (2012).

30. Atsumi, M., Park, S.-H. \& Wang, H.-L. Methods used to assess implant stability: current status. Int. J. Oral Maxillofac. Implants 22, 743-54 (2007).

31. Choi, H.-H., Chung, C.-H., Kim, S.-G. \& Son, M.-K. Reliability of 2 implant stability measuring methods in assessment of various periimplant bone loss: an in vitro study with the Periotest and Osstell Mentor. Implant Dent. 23, 51-6 (2014).

32. Çehreli, M. C., Karasoy, D. \& Kökat, A. M. A systematic review of marginal bone loss around implants retaining or supporting overdentures. J. Prosthet. Dent. 105, 4 (2011).

33. Albrektsson, T. in Proceedings of the First European Workshop on Periodontology 243-244 (1994).

34. Jung, Y. C., Han, C. H. \& Lee, K. W. A 1-year radiographic evaluation of marginal bone around dental implants. Int $J$ Oral Maxillofac Implant. 11, 811-818 (1996).

35. Komiyama, A., Hultin, M., Näsström, K., Benchimol, D. \& Klinge, B. Soft Tissue Conditions and Marginal Bone Changes around Immediately Loaded Implants Inserted in Edentate Jaws Following Computer Guided Treatment Planning and
Flapless Surgery: A $\geq 1$-Year Clinical Follow-Up Study. Clin. Implant Dent. Relat. Res. 14, 157-169 (2012).

36. Tokuhisa, M., Matsushita, Y. \& Koyano, K. In vitro study of a mandibular implant overdenture retained with ball, magnet, or bar attachments: comparison of load transfer and denture stability. Int. J. Prosthodont. 16, 128-134 (2003).

37. ELsyad, M. A., Omran, A. O. \& Fouad, M. M. Strains Around Abutment Teeth with Different Attachments Used for Implant-Assisted Distal Extension Partial Overdentures: An In Vitro Study. J. Prosthodont. 26, 4247 (2017).

38. Assad, A. S., Hassan, S.A., Shawky, Y.M. \& Badawy, M. M. Clinical and Radiographic Evaluation of ImplantRetained Mandibular Overdentures With Immediate Loading. Implant Dent. 16, 212-223 (2007).

39. Bilhan, H., Mumcu, E. \& Arat, S. The comparison of marginal bone loss around mandibular overdenturesupporting implants with two different attachment types in a loading period of 36 months. Gerodontology 28, 49-57 (2011). 